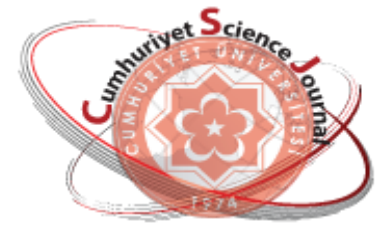

e-ISSN: $2587-246 X$

ISSN: $2587-2680$

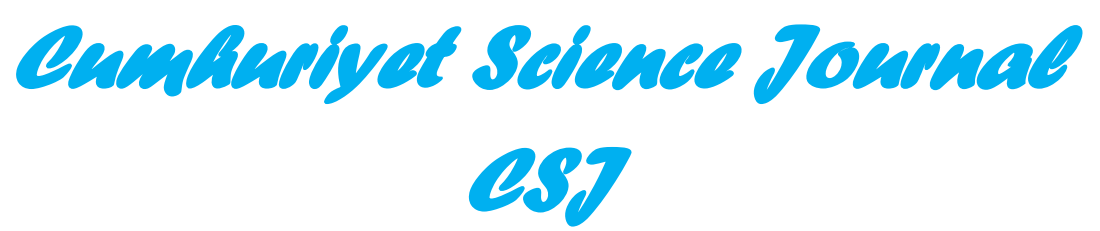

Cumhuriyet Sci. J., Vol.40-2 (2019) 487-492

\title{
Determination of Dangerous Parts of the Energy Transmission Line by the Canopy Height Model Produced from LiDAR Data
}

\author{
Nuray BAŞ \\ Istanbul Technical University, Department of Geomatics Engineering, Istanbul, TURKEY
}

Received: 25.02.2019; Accepted: 18.06.2019

http://dx.doi.org/10.17776/csj.461375

\begin{abstract}
LiDAR (Light Detection and Ranging) technique is preferable method to determine vertical metric values of High Voltage Transmission Lines (HVTL) in global regions and steep land. The importance of these facilities is increasing day by day because of the necessity of electricity energy in our daily life. Determination of vertical heights is an important problem especially in forested areas after construction. In this study, metric values of vegetation which violate vertical safety limits under voltage wires were determined by using Canopy Height Model (CHM) using LiDAR data. As a study area 450x150 $\mathrm{m}^{2}$ was selected the existing voltage line in the region between Beykoz District and Çekmeköy located on the Anatolian side of Istanbul. Firstly, it has been made conductive classification of HVTL that is using LiDAR classification techniques. Also it is determined the dangerous limits of trees and vegetation in HVTL vertical oscillation. As a result the comparison of the values of the vertical elevation with the local methods and obtained from the LiDAR data yielded a Root Mean Square Error (RMSE) value of $0.36 \mathrm{~m}$ was found..
\end{abstract}

Keywords: LIDAR, Classification, Canopy Height Model, Power Transmission Line.

\section{LiDAR Verilerinden üretilen Kanopi Yükseklik Modeli Yardımıyla Enerji Nakil Hattının Tehlikeli Kısımlarının Belirlenmesi}

\begin{abstract}
Özet. LiDAR (Light Detection and Ranging) tekniği özellikle ulaşılması zor ve global alanlarda, Enerji Nakil Hatları (ENH) gibi tesislerin düşey metrik değerlerinin belirlenmesi konusunda tercih edilebilir bir yöntem olarak karşımıza çıkmaktadır. Elektrik Enerjisi ihtiyacının günlük yaşamımızda hayati bir ihtiyaç halini alması bu tesislerin önemini her geçen gün artırmaktadır. Tesisinden sonraki aşamada ise, düşey yüksekliklerin tespit edilmesi de özellikle ormanlık alanlık alanlarda önemli bir sorun olarak karşımıza çıkmaktadır. Bu amaçla yapılan bu çalışmada, LiDAR verileri kullanılarak oluşturulan Kanopi Yükseklik Modeli(KYM) yardımıyla gerilim telleri altındaki düşey emniyet sınırlarını ihlal eden bitki örtüsünün metrik değerleri belirlenmiştir. Çalışma alanı olarak İstanbul ilinin Anadolu yakasında yer alan Beykoz İlçesi ile Çekmeköy ilçesi arasındaki bölgedeki mevcut Enerji Nakil Hattını kapsayacak şekilde 450 x150 m2 'lik bir alan seçilmiştir. İlk olarak, Enerji Nakil Hattının LiDAR sınıflandırma teknikleri ile iletken sınıflandırması yapılmış ve elde edilen yükseklik değerlerinden, ENH düşey salınım içerisine giren bölgedeki ağaçların ve bitki örtüsünün tehlikeli sınırları tespit edilmiştir. Elde edilen sonuçlar yersel yöntemler ile elde edilen yükseklik değerleriyle karşılaştırılmış olup $\mathrm{KOH}$ değeri 0.36 m olarak bulunmuştur.
\end{abstract}

Anahtar Kelimeler: LiDAR, Sınıflandırma, Kanopi Yükseklik Modeli, Enerji Nakil Hatları.

\footnotetext{
* Corresponding author. Email address: nuraybas@gmail.com

http://dergipark.gov.tr/csj C2016 Faculty of Science, Sivas Cumhuriyet University
} 


\section{INTRODUCTION}

Light Detection and Ranging (LiDAR) is an active remote sensing technique which uses electromagnetic energy in optical range to detect an object using distance between the target and sensor

System includes three basic data collection tools which is consisting of laser scanner, Global Positioning System (GPS) and Inertial Measurement Unit (IMU) systems. In recent years, LiDAR techniques have been used in many areas from mapping to urbanism and mining. Since vertical accuracy is more sensitive than positioning accuracy, there are many applications related to this technique in Digital Elevation Model (DEM) and Digital Surface Model (DSM). It is an advantage to obtain high-accuracy threedimensional coordinate information in areas such as steep slopes, hills and forested area that cannot be reached by traditional method. Especially in corridor mapping applications for example Highvoltage Transmission Lines (HVTL) project.

Many studies have been made in the literature such as object identification, DSM, DTM and accuracy management by using LiDAR data. Some studies about determination of HVTL and calculation of vertical distances have also been found in these studies. For example; HVTL and classification techniques have been studied [2]. On the other hand had practiced the risk management of lines [3]. Also identified automatic clearance with the smallest distance differential geometry calculations. Using the height threshold value applied the pylon and mask technique to the point cloud have been done [4]. They used the space, shape and symmetry properties of objects. [5] have identified the trees which is entering the Power Line corridor in the forested area. They applied random clustering method using height shape, growth characteristics in a determined area. In other study, it has been implemented plant management practices in transmission line corridor [6]. They defined the conductor wires by a semi-automatic classification process and used the buffer algorithm. Then, determined polygonal zones where vegetation on the dangerous voltage line. [7] identified the power line by using height threshold segmentation and height density segmentation algorithm.
In this study, it is aimed to determine the Canopy Height Model (CHM) segmentation of the dangerous parts of plants and trees entering into the vertical clearance of the HVTL using LiDAR data in forested area.

\section{STUDY AREA}

Istanbul Province, located in between the Beykoz and Çekmeköy existing HVTL route which is forested area in the district, $450 \times 150 \mathrm{~m}^{2}$ of a rectangle is selected (Figure 1).

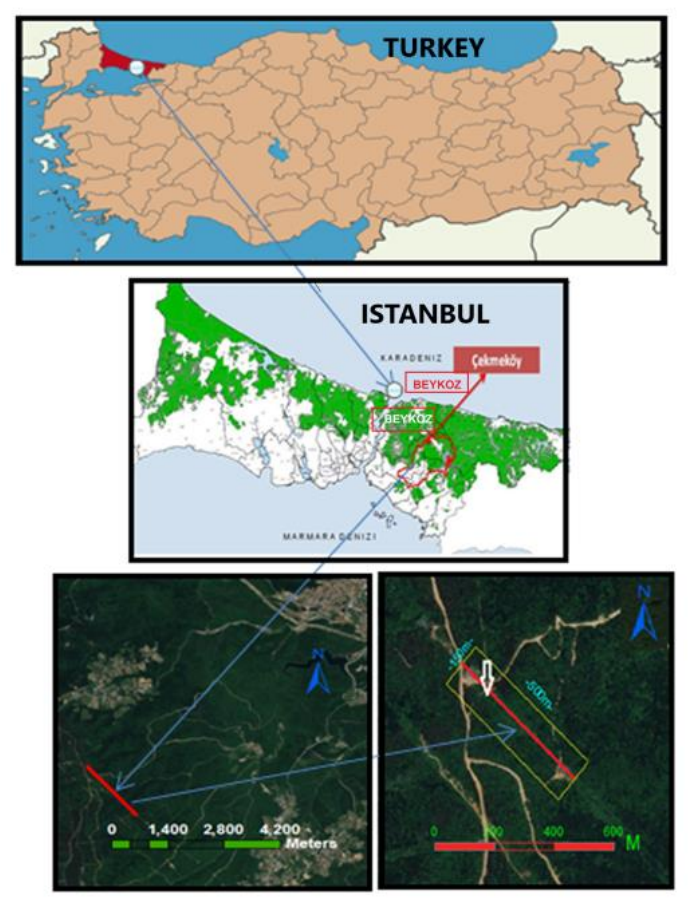

Figure 1 : Study Area

\section{MATERIAL AND METHOD}

The LiDAR data was obtained by using the Riegle LMS-Q560 LiDAR scanner at an average speed of $700 \mathrm{~m}(80 \mathrm{~km} / \mathrm{h})$ at 16.10 .2016 . The system parameters of the data are shown in the Table 1. 
Table 1. System Parameters of Airborne LiDAR Data Used

\begin{tabular}{ll}
\hline \hline \multicolumn{1}{c}{ System Parameters } \\
\hline Flight Speed & $80 \mathrm{~km} / \mathrm{h}$ \\
Flight Altitude & $700 \mathrm{~m}$ \\
Scan Angle & $30^{\circ}$ \\
Pulse /second & $200.000(1 / \mathrm{sn})$ \\
Laser Beam Divergence & $0.5 \mathrm{mrad}$ \\
Raw Data Density & $5 \mathrm{point} / \mathrm{m}^{2}$ \\
Point spacing & $0.8 \mathrm{~m}$ \\
\hline
\end{tabular}
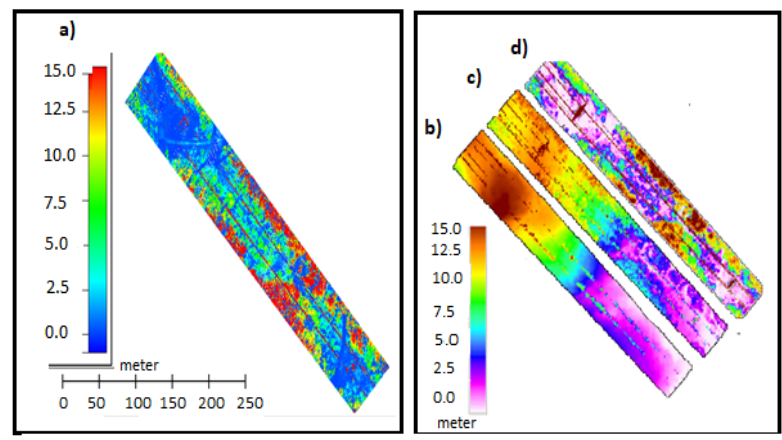

In the first phase of the study, the existing Raw LiDAR data is classified as ground and nonground points. Removing the noise points before the classification process is important for both classification and model accuracy. Adaptive Triangulated Network (ATIN) filtering method was applied in the classification process [8]. LiDAR 360 commercial software was used as software.

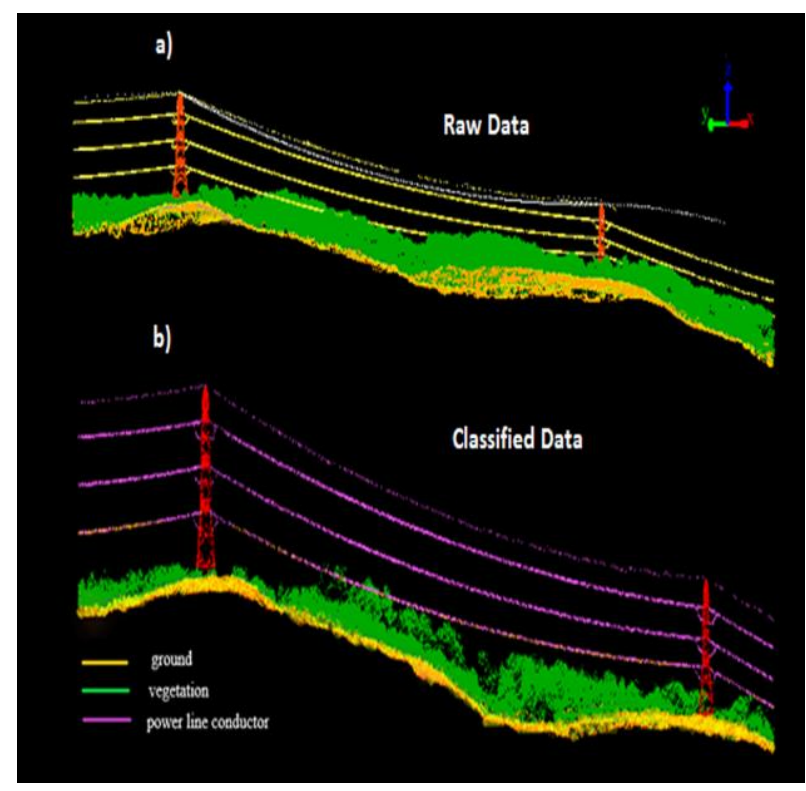

Figure 3: a) Height diagram of Point Cloud Image; b) Digital Terrain Model (DTM) c) Digital Surface Model (DSM) d) Canopy Height Model (CHM)

In the third phase; It is aimed to estimate the height values of the vegetation and trees under HVTL route and also to determine the dangerous limits for the power line wires.

In step four, the total station measurement results of the existing power transmission line obtained terrestial method from the project file of the HVTL. These values are used for accuracy management.

\section{DISCUSSIONS OF RESULTS AND CONCLUSIONS}

Today, new energy sources are explored every year to provide energy needs in our country. For this purpose it has been establish a new Transmission Line facility in Istanbul every year. Because the city's population and demand for energy is increasing day by day.

Figure 2: a) Raw LiDAR Data b) Classified Data

In the second step, point cloud data was transformed into grid structure in $1 \times 1 \mathrm{~m}$ cell size. Then, CHM was generated from normalized LiDAR height value using raster data. Figure $3 \mathrm{a}$ shows the height diagram of the classified data. Also CHM is created the differences of DSM and DTM (Figure3b-c-d).

As a tehcnical rule, power line are planned as shortest route and pass through worthless land. But sometimes also through forested areas. In this case, vegetation or tree branches extending towards the vertical tension wires damage the voltage lines. As a result, it can be energy loss and power failure. Also, a fire hazard may ocur especially in summer period. Trees should be pruned in summer for these undesirable situations. For solution the minimum distance between the transmission line wires and the vegetation must be maintained. But it is difficult and wast of time to 
follow the branches of trees that extend through the wires with traditional ground measurement techniques. In forested area, tree height, tree size, and canoppy area defined preciselly estimates [9] used LiDAR techniques. This technique is able to determine the elevation information of large areas both high accuracy and faster than traditional method [10].

Vertical distance from the ground to the maximum sag of the wire was measured. Buffer size is selected according to the maximum width on transmission corridor (right of way) which is determined as $60 \mathrm{~m}$ (Figure 4).

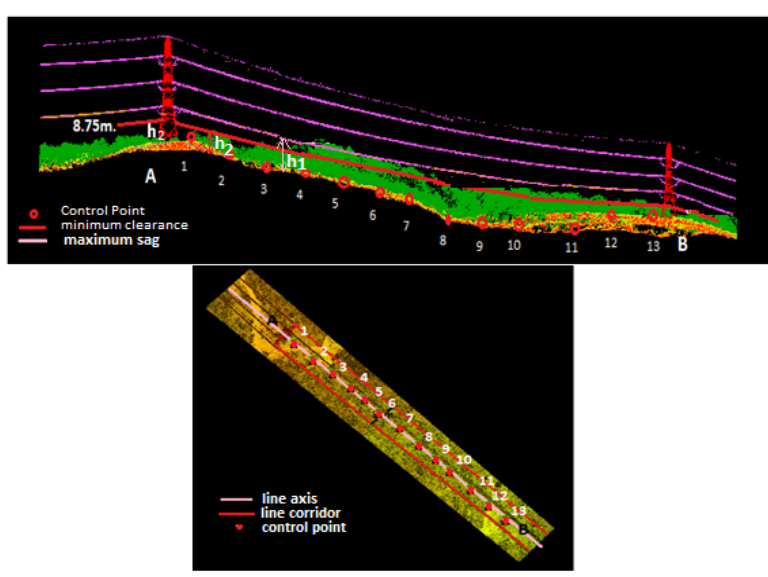

Figure 4: Horizontal and Vertical Profile of the Study Area

The minimum clearance of voltage line in the classified LiDAR data is called $\mathrm{h} 1$. But maximum sağ and full load in hot day determined which is $8.75 \mathrm{~m}$ called $\mathrm{h} 2$. The sag lower clearance to the ground depending on ambient temperature and also operating conditions. Minimum vertical clearance which is depending at this value maintained from right of way. The safety distance from the conducter that no human plant and building into safety limits should approach. Minimum clearance limits determined by regulations for the $380 \mathrm{kV}$ Lines according to the High Current Directive published in the Official Gazette numbered 24246 on 30.11.2000 [11]. According to these rules, minimum clearance to be calculated is shown with Equation 1.

minimum safety clearance $=\mathrm{h} 1-\mathrm{h} 2$
In this study, the voltage line within the study area was determined by classification process. It is important classification process for he accuracy metric value. After the detection of voltage line and also maximum sag a point was thrown at every $25 \mathrm{~m}$ between the A-B length.

In principle, pixel based segmentation method was applied with the height values in each region. The parameter values used in the segmentation process are shown in the Figure 5.

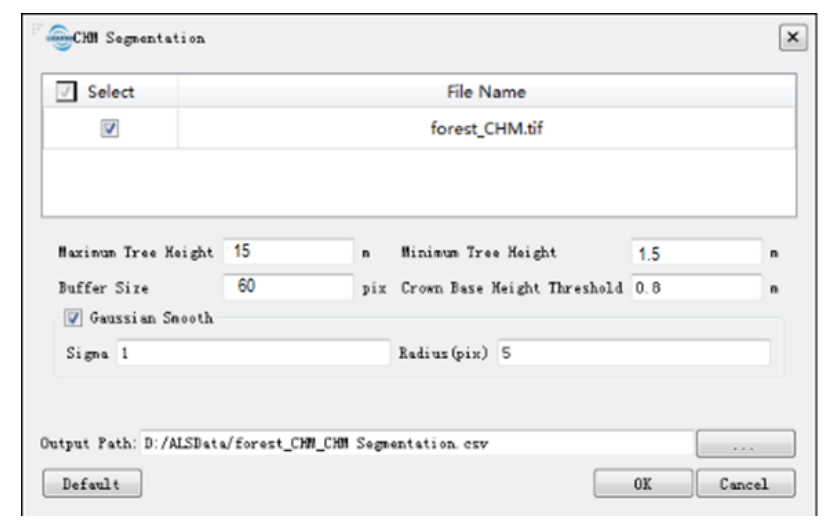

Figure 5 : Threshold Value of Segmentation Process

As a rule, CHM pixels above maximum three height threshold will not be considered in the segmentation. In the same time, CHM pixels below min tree height threshold will not be considered in the segmentation. Crown Base Height Threshold is the starting height of the crown range. A reasonable base height value is very important to improve the accuracy of the results.

As a result of this section, obtained individual tree information, such as tree location, tree height, crown diameter, crown area provides extremely precise estimates of tree height, and there are defined relationships between tree height or canopy area and tree size (i.e., diameter) [10].

Table 1 are included in minimum clearance, tree heights, volume and diameters for each numbered control point section. For implementation, If the tree height is greater than the measured minimum clearance value, it is called a danger zone. The trees in this area should be cut to the minimum clearance to avoid any danger. 
Table 2: CHM Segmentasyon Result

\begin{tabular}{ccccccc}
\hline \hline Number & $\begin{array}{c}\text { Tree height } \\
(\mathbf{m})\end{array}$ & $\begin{array}{c}\text { Danger } \\
\text { zone }\end{array}$ & $\begin{array}{c}\text { Min } \\
\mathbf{c l e a r a n} \\
\mathbf{c e}\end{array}$ & $\begin{array}{c}\text { Total Station } \\
\left(\mathbf{h}_{\mathbf{1}}-\mathbf{h}_{\mathbf{2}}\right)\end{array}$ & $\begin{array}{c}\text { Tree } \\
\text { Diameter } \\
(\mathbf{m})\end{array}$ & $\begin{array}{c}\text { Volume } \\
\left(\mathbf{m}^{\mathbf{3}}\right)\end{array}$ \\
\hline 1 & 3 & - & 6.31 & & & \\
2 & 4 & - & 7.52 & 7.03 & 10.99 & 95 \\
3 & 9 & - & 9.45 & 9.27 & 9.23 & 67 \\
4 & 12 & danger & 11.21 & 10.97 & 7.13 & 40 \\
5 & 16 & danger & 14.03 & 13.83 & 11.62 & 244 \\
6 & 11 & danger & 9.46 & 9.23 & 6.86 & 37 \\
7 & 10 & danger & 6.78 & 5.82 & 5.04 & 20 \\
8 & 5 & danger & 3.96 & 3.71 & 7.48 & 44 \\
9 & 4 & danger & 2.75 & 2.75 & 7.73 & 47 \\
10 & 6 & danger & 2.50 & 2.14 & 6.18 & 30 \\
11 & 7 & danger & 2.70 & 2.34 & 9.44 & 70 \\
12 & 5 & danger & 2.21 & 1.95 & 4.65 & 17 \\
13 & 5 & danger & 4.02 & 3.82 & 7.31 & 42 \\
\hline
\end{tabular}

For the accuracy management, the terrestrial measurement results and the lidar height values were compared. The amount of error in height values is calculated with Root Mean Square Error (RMSE) and found as $0.36 \mathrm{~m} \mathrm{(2).}$

$\mathrm{RMSE}_{\mathrm{z}}=\sqrt{\frac{\sum_{i=1}^{n}\left(\text { Lidar }_{z}-G P S_{z}\right)^{2}}{n}}=0.36 \mathrm{~m}$.

As a result it has been possible that the detection and management of the danger parts of trees and vegetation under the power line. In the forested areas that are similar to the working area, it will be difficult to mapping by the local methods, thus taking into consideration the accuracy obtained, time and power will be saved. It is also possible to monitor the dangerous occurrences on the energy transmission line if data are available at specific intervals.

\section{Acknowledgements}

I want to thank TEİAŞ (Turkish Electricity Transmission Corporation) for the supply of data.

Note: Different part of this study was previously presented as an only oral presentation in 4th International Scientific Research Congress (UBAK-Yalova)

\section{REFERENCES}

[1] Diaz, J.C.F., Carter, W.E., Shrestha R.L. and Glennie, C.L. Handbook of Satellite Applications, (2017) 929-980.

[2] Li, X. and Guo, Y., Application of LiDAR technology in power line inspection. IOP Conference Series: Materials Science and Engineering, 382 (2018) 052025.

[3] Chen, C., Yang, B., Song, S., Peng, X. and Huang, R. Automatic clearance anomaly detection for transmission line corridors utilizing UAV-Borne LiDAR data. Remote Sensing, 10-4 (2018) 613.

[4] Awrangjeb, M., Islam, M. K. and Systems, I., Classifier-Free Detection of Power Line Pylons From Point Cloud, 14-15 (2017). 8187.

[5] Ko, C., Remmel, T. K. and Sohn, G.. Mapping tree general using discrete LiDAR and geometric tree metrics, Bosque (Valdivia), 33-3 (2012) 29-30.

[6] Kurinsky, B. H. and Hung, M.C. Identification and Visualization of Vegetation Encroachments along Power Line Corridors using LiDAR, International Journal of Research in Geography, (IJRG), 11 (2015) 38-51. 
[7] Shen, X., Qin, C., Du, Y., Yu, X. and Zhang, R. An automatic extraction algorithm of high voltage transmission lines from airborne LiDAR point cloud data. Turkish Journal of Electrical Engineering and Computer Sciences, 26-4 (2018) 2043-2055.

[8] Axelsson, P.E. DEM generation from laser scanner data using adaptive TIN models. International Archives of the Photogrammetry, Remote Sensing and Spatial Information Sciences, 32 (2000) 110-117.

[9] Meador, A.J.S. and Parysow, P.F., and Moore, M.M. A new method for delineating tree patches and assessing spatial reference conditions of ponderosa pine forests in northern Arizona, Restoration Ecology 19-4 (2011) 490-499.

[10] Hodgson, M.E. and Bresnahan, P. Accuracy of Airborne LiDAR-Derived Elevation: Empirical Assessment and Error Budget, Photogrammetric Engineering and Remote Sensing, 70 (2004) 331-339.

[11] Regulation on Electric Power Installations, published in the Official Gazette No. 24246 dated $\quad 30 \quad$ November 2000. http://www.resmigazete.gov.tr/eskiler/2000/1 1/20001130. 